\title{
DECEMBER IS WINTER
}

\section{I}

If I am preoccupied with the tropics

let it be: place of birth, mud, soliloquies,

or madness that lies fallow in the brain-

Containing the self accustomed to acacia, black sage, bougainvillea that flounder like brain cells, which invariably come back to haunt

No matter in what region of a white wilderness.

Snow in the yard, Lake Superior in the background:

such a complexion really, or always mapping out territory because of blind ambition or affectation.

\section{II}

Closer to green grass, a ball ricochets in the sun; an old man - a grandfather whom I hardly knew: who scolded from afar, a stroke doing him in finallythe tropics' own, like a dream in swirling heat.

At last outmanoeuvring the self at every angle, I am at a standstill; the lake almost glass, with memory like foam rising higher, ochreous sandy beach with taller palm trees outdoing other miracles in the forgetful sun.

Questioning motives is all I ask, the temperate impulse to flaunt with banana leaves once in a while, or a tenement on a side street becoming bedraggled: the story of one's life so far, singing in the mud. 